\title{
バーチャルリアリティにおける身体図式キャリブレーションに 触力覚フィードバックが及ぼす影響
}

望月 典樹*1, 中村 壮亮*2, 橋本 秀紀 ${ }^{* 3}$

\section{The effect of haptic feedback on body scheme calibration under virtual reality}

\author{
Noriki MOCHIZUKI*1 ${ }^{*}$, Sousuke NAKAMURA ${ }^{* 2}$ and Hideki HASHIMOTO* ${ }^{* 3}$ \\ ${ }^{{ }^{*} 1,{ }^{* 3}}$ Department of Science and Technology, Chuo University \\ 1-13-27 Kasuga, Bunkyo-ku, Tokyo 112-8551, Japan \\ ${ }^{* 2}$ Department of Electrical and Engineering, Faculty of Engineering, Hosei University \\ 3-7-2 Kajinochou, Koganei-shi, Tokyo 184-8584, Japan
}

Received: 18 January 2017; Revised: 16 April 2017; Accepted: 15 June 2017

\begin{abstract}
Immersive virtual reality system has a problem that the operability deteriorates if the shape of the virtual body is parted from the real body. The authors are assuming that this is caused by misfit of the body scheme, an internal model in the brain used to recall the body position, because it is initially tuned up to the real body instead of virtual body. Thus, the authors have proposed a method using VR technology called "Body Scheme Calibration" to change the body scheme adapting to the real body so as to fit the virtual body. However, in the previous approach, presented VR information was limited to visual information, and haptic information normally occurring from interaction with surrounding object was neglected. Therefore, this paper investigated the effect of haptic information on Body Scheme Calibration. As an experimental result, it was verified that the effect of additional haptic information is trivial, and the complex haptic interface for this calibration might be omissible.
\end{abstract}

Key words : Virtual reality, Body scheme calibration, Body image, Haptics, Multisensory integration

\section{1.は じめ に}

コンピュータで生成した情報を現実であるかのように感じさせるVR（Virtual Reality）の研究領域では，人間へ の情報提示に関する方法論という観点でみると，知覚や認知などの脳機能を踏まえた検討が不可欠であり，人間 を含めたシステムという位置付けで研究が行われている。一般にVR システムでは, 感覚情報の提示とユーザ情 報の取得が並列かつ同時に行われる必要がある．これらの実現によりユーザは，仮想空間内の身体（以降，仮想 身体）を操作することで，仮想空間とインタラクションすることが可能になる．また近い将来の実現が期待され る完全没入型の VR システムでは，仮想空間で扱われる情報が実空間と同程度となり，仮想身体をあたかも自分の 身体のように扱うことが可能になると予想される.

$1 \cdot 1$ 仮想身体の操作における問題とその原因

VR の特徵として，実空間に存在しない物体を生成することや，起こり得ない状況を意図的に発生させられると いった利点がある。これは仮想身体に対しても例外ではなく，例えば自身と寸法が異なるアバタやテレプレゼンス

\footnotetext{
No.17-00022 [DOI: 10.1299/transjsme.17-00022], J-STAGE Advance Publication date : 29 June, 2017

${ }^{* 1}$ 中央大学理工学部（T112-8551 東京都文京区春日 1-13-27）

*2 正員, 法政大学理工学部（广184-8584 東京都小金井市梶野町 3-7-2)

*3 正員, 中央大学理工学部

E-mail of corresponding author: mono.gmllab@gmail.com
} 


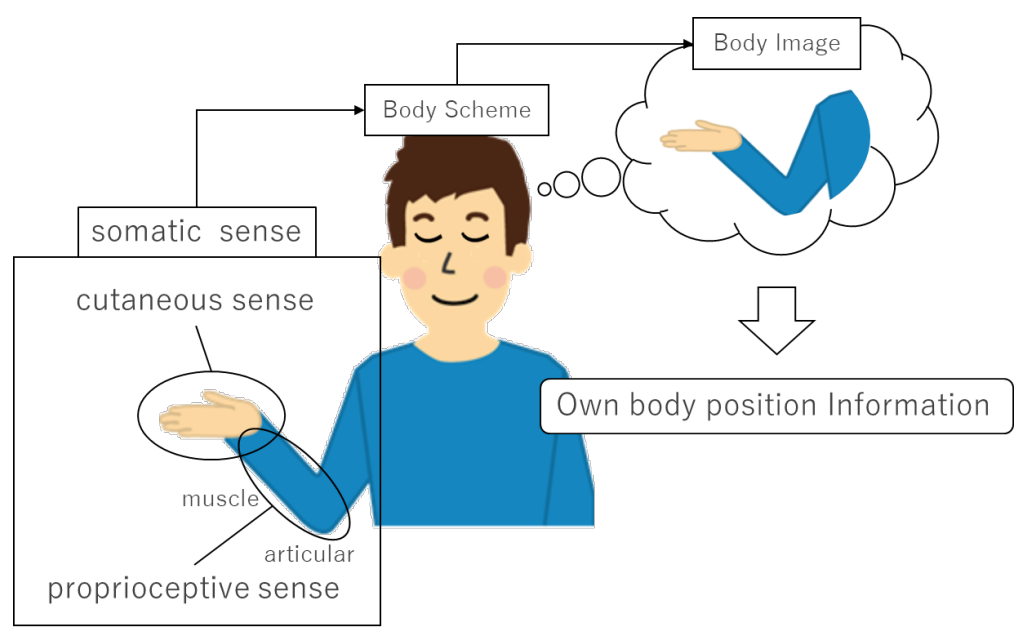

Fig. 1 Body image recalled through body schema in the brain from somatosensory inputs.

用の汎用遠隔ロボットなど，操作対象の物理特性を容易に変更することができる. (Hightower et al., 1986) (Stark et al., 1987) (Sato, 1992) (Oyama et al., 1993) (Burdea, 1999). この利点を活かすことで，エンタテイメントやコミュ ニケーションッール (Giuseppe, 1999) といった一般的な用途から, 遠隔ロボットによる災害支援や医療 (Fang and $\mathrm{Wu}, 2014)$ などの特殊用途にまで応用が期待されている.

しかしながら，ユーザが実身体と形状の異なる仮想身体を操作する場合，その操作性が低下し，意図した動作 が実現できなくなるといった問題が報告されている (渡邊他, 2009). 実際に身体寸法の統計データ (Digital Human Research Group, 2003) を参照してみると, 例えば前腕長は平均值 $(\mathrm{m}): 251.6[\mathrm{~mm}]$ ・標準偏差 $(\sigma): 12.54[\mathrm{~mm}]$ と なっており，平均值に対して最大で約 $\pm 15 \%(3 \sigma)$ の寸法差が発生し得るようである.

この問題に対するアプローチとして, テレプレゼンスの用途に限っては, 遠隔ロボットの寸法に合わせるように 仮想身体を相似系で拡大・縮小するスケーリングと言われる手法 (柳田, 涻, 2002) (Furukawa et al., 2014)や, 仮想 身体を遠隔ロボットの形状とせずに実身体のままとし，その身体での動作結果を変換して遠隔ロボットの動作を決 定するという，拡張テレプレゼンスを用いた手法 (Tachi et al., 1988) (大山他, 1994, 2002) が考えられる. しかしな がら，スケーリングについては実身体と仮想身体が非相似系で異なる場合に身体の一部しか整合させることがで きないという欠点があり, 拡張テレプレゼンスでは, 実身体の動作と遠隔ロボットの動作の対応データをモデルと いう形で蓄積する必要があり, これが目的の動作の数だけ必要になるという点で実用的でないという問題がある.

そこで著者らは，操作性低下の根本的な原因が身体図式の乘離にあると考え，実身体に適合している身体図式を 仮想身体のものへと変更するという「身体図式キャリブレーション」について基礎検討を行ってきた. (Nakamura et al., 2014) (依田他, 2015)

\section{2 身体図式変更による仮想身体の操作性向上の展望}

身体図式とは, 視覚・聴覚・体性感覚などの感覚情報の入力により身体の状態に関する情報 (形状, 寸法, 位置 姿勢など）を出力する脳機能であり, 意識に上った身体の状態は身体像と呼ばれる. 図 1 に示すように, 身体図 式に基づき皮雐感覚や固有受容感覚などの体性感覚入力から身体像が想起されるため, 視覚入力を断っても身体 各部の位置姿勢が把握できるのである (Head and Holmes, 1911). なお身体図式は, 行為に伴う感覚情報の脳内統 合を通して学習・構築される.

実身体と形状の異なる仮想身体を操作する場合, 実身体の身体図式を転用出来ないことが仮想身体の操作性低下 を招くと考えられる.これは，仮想身体と自分の実身体とを切り離して別物として認識している状況である. 従っ て，何らかの方法で，仮想身体の形状に適合するように身体図式を変更できれば，仮想身体をあたかも自分の身 体であるように操作できることとなり, 操作性の向上が期待される. 
Table 1 Feature of each method for changing of body scheme.

\begin{tabular}{|c|c|c|c|c|c|}
\hline & Occurrence Condition & Learning Time & Accuracy & Precision & Target \\
\hline Growth of body / Loss of body & \multirow[t]{2}{*}{$\times$ Naturally } & $\times$ Long & \multirow[t]{2}{*}{$\circ$ High } & \multirow[t]{2}{*}{$\circ$ High } & $\circ$ Own body \\
\hline Tool-use & & oShort & & & $\times$ Other object \\
\hline Auditory illusion & \multirow[t]{2}{*}{ oActively } & & $\times$ Low & $\times$ Low & \multirow[t]{2}{*}{$\circ$ own body } \\
\hline Proposed method & & & $\triangle$ Middle & $\circ H i g h$ & \\
\hline
\end{tabular}

\section{$1 \cdot 3$ 身体図式変更手法とその現状}

身体図式は，視認した自己身体映像が身体像の教師信号として体性感覚と紐づけられることで学習されると考え られている (Maravita and Iriki, 2004) (Roschin et al., 2011) (Fuke et al., 2009). 学習によって身体図式が変化する例 としては, 自然発生的なものでは身体の成長 (Bushnell and Boudreau, 1993) や欠損 (Bromage and Melzack, 1974), 能動的なものでは音による錯覚 (Tajadura-Jimenez et al., 2012) があり，さらには道具使用時に自己身体以外に延長 されるといった報告もある (Maravita and Iriki, 2004) (Cardinali et al., 2011). ここで音による錯覚とは，指先で床な どを吒打する際に, 打音の発生位置を恣意的に遠方に変えることで腕が伸びたように感じるといった現象である.

しかしながら，これらの研究報告は何れも現象確認に留まっているため，仮想身体に対して身体図式を適合させ る方法として，VR システムに身体図式を変更する機能を組み込むためには，実用を意識しての検討が必要となっ てくる．特に上記用途では，自己身体に関する身体図式の変更が能動的，短時間，高確度，高精度に実現可能で あることが求められる。そこで著者らは，身体寸法の変化を無意識的に知覚させるVR 情報を視覚提示した状態 で，仮想物体に触れる運動を行わせることにより，寸法変更後の身体と体性感覚との紐づけを促進させて身体図 式を変更するという手法を提案し，その有効性を示してきた (Nakamura et al., 2014) (依田他, 2015). 著者らがこれ までに提案した手 法の位置付けを表 1 に示す.

しかし，著者らの提案手法において提示したVR 情報は視覚情報に限定しており，物体との接触時に発生する触 力覚情報については再現されていなかった. 触力覚情報による体性感覚入力への影響は身体図式の変更に影響を 与える可能性がある，従って本論文では，身体図式の変更に対して触力覚情報が与える影響を調査する.

\section{4 本研究の目的}

本論文では，VR システムにおける触力覚情報の提示が身体図式の変更に及ぼす影響を明らかにすることを目的 とする.

身体図式の学習過程で利用される体性感覚入力に属する触力覚情報の付加は，獲得される身体図式に影響を与 える可能性がある。一方で，一般に人間は視覚に依存していると言われているため，触力覚情報の影響は少ない とも考えられる．仮に影響が僅かであった場合はシステムの複雑さが増す触力覚提示機能の導入は必須でないと いうことになり，システム簡略化の有益な情報となりうる.

また，このような工学的な観点のみならず，人間の認知特性の解明という自然科学的な側面においても，本研究 によって得られる知見は重要なものである.

\section{2. 視覚的な VR 情報提示による身体図式変更手法}

本論文では著者らの先行研究 (Nakamura et al., 2014) (依田他, 2015) で扱った視覚的な VR 情報の提 示による身 体図式変更手法をベースとして, 触力覚情報を追加提示した際の影響を調査する.そこで初めに, ベースとなる 先行研究における身体図式の変更手法とその変更度合いの評価方法について説明する.

\section{$2 \cdot 1$ 身体図式の変更手法}

まず身体図式は，身体像の教師信号を体性感覚と意識的に紐づけることで学習されるため，運動実行による体 性感覚入力が第一に必要となる．また学習時間を短くするためには，視覚情報の遮断により体性感覚に基づく身体 像を意識させることが有効である. しかし, 視覚情報を常時遮断した場合, 教師信号に正確な身体映像を利用でき なくなり，身体図式の確度が低下してしまう。そこで著者らは，以下の二つの学習過程をハイブリッドで行う身体 


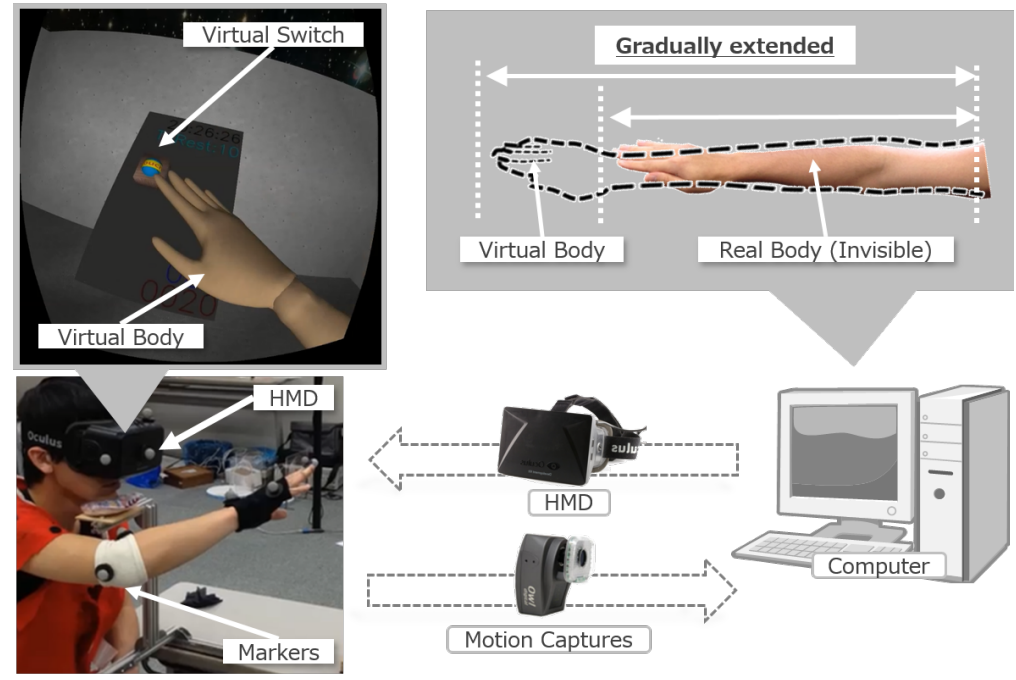

Fig. 2 Configuration of the system developed in the previous research(Nakamura et al., 2014).

図式変更手法（ハイブリッド学習）を考案した。なおこの際，身体図式を变更する対象は右前腕に設定している.

（1）変更目標の身体像に合致した身体映像が視覚提示された状態で運動を行う学習過程

（2）身体映像は遮断した状態で, 変更目標の身体像に合致した指先位置のみを間接的に視覚提示し, そこから想 起される身体映像を教師信号として，体性感覚主導の運動を行う学習過程

このハイブリッド学習を実現するためのシステムは，ユーザの位置姿勢情報を取得するためのモーションキャ プチャ，VR 情報を視覚提示する HMD，モーションキャプチャの情報に基づきVR 情報を生成するための PC から なる．システム構成の概要を図 2 に示す．システムでは，実身体の位置を基に仮想身体の右腕を重畳する形で配 置し, 右前腕に限りその形状と位置関係を実身体に対する比率として, 肘から手首に向かう方向へ伸長可能とし てある。これにより変更目標の身体図式に合致した身体映像は伸長比という形で生成できる。また仮想身体の表 示・非表示は切り替え可能となっている．体性感覚入力を伴う運動としては，仮想空間にランダムで出現する仮 想スイッチを仮想身体の右手指先で押す課題（スイッチングタスク）を設定し，仮想スイッチが指先と接触した 時にその形状を変化させることで，スイッチングの成功を視認可能としている．これにより，目標の身体像に調整 した仮想身体を表示した状態でスイッチングを行うことによって学習過程 (1)を実現し，さらに仮想身体を非表示 とした状態で，スイッチ押下に伴う形状変化により指先位置を間接提示することで学習過程 (2) を実現している.

なお，これらの学習過程による効果は，仮想身体と自己身体の寸法が一致していると錯覚していることが前提 となる．そこで，仮想身体への自己所有感を高めるために以下二つの工夫を行っている.

(i) 図 3 のように，実空間と仮想空間において同位置に存在する MR（Mixed Reality）スティックを用意し，身体 定位が正確な部位（指先, 手首, 肘など）をスティックで撫でる過程をスイッチングタスクの前に実施する. これは外部物体に自己所有感が転移される現象である RHI(Rubber Hand Illusion) を参考とした．RHI とは，視 覚遮蔽された実腕と，視野内に置かれたラバーハンド（手の形状をしたゴム製の物体）に対して，同期した 触刺激を絵筆などで一定時間与え続けると，ラバーハンド上に触刺激を知覚し，さらにラバーハンドへの自 己所有感が増すという錯覚現象である.

(ii) 仮想身体と実身体の寸法の差異が意識に上らないよう，仮想身体の伸長比を最初から目標値とせず，初期值 を比率 1.0 として, スイッチングタスク中に徐々に目標の伸長比へと変化させる. これはディスプレイに身体 


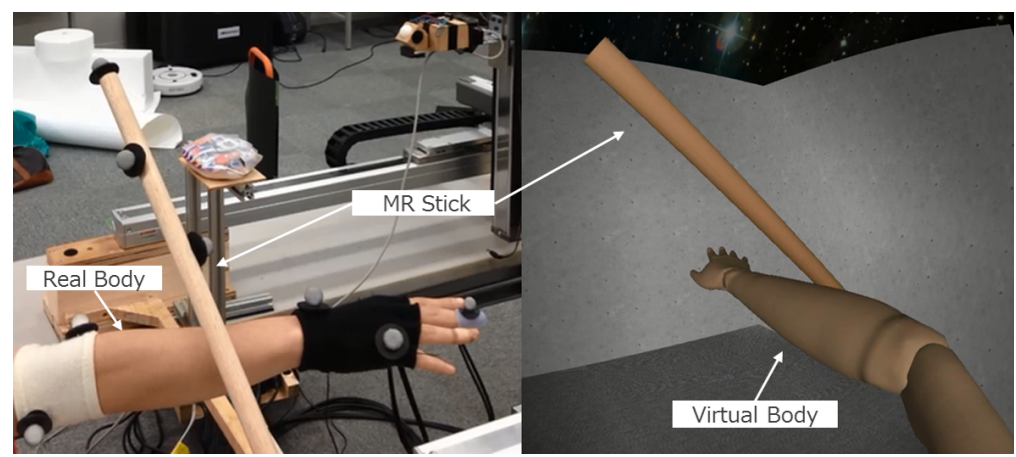

Fig. 3 Process to increase the sense of ownership against virtual body by use of MR stick.

を重畳表示した状態で，認知できないレベルでその位置関係を操作することで，身体の認識を実際の位置か らスライドさせた (Roger, et al., 2012) と類似した手法である.なお目標値での学習機会を十分に確保するた めに, 目標值到達後も十分な回数のスイッチングを行わせる.

\section{$2 \cdot 2$ 身体図式変更度合いの評価方法}

身体図式は脳内モデルであるため, 出力された身体位置姿勢情報を直接測定するのは困難である，そこで体性 感覚入力に伴い身体図式より出力される身体位置姿勢情報が確実に利用される動作において，その位置関係から 間接的に身体図式の変化を捉える. 具体的には，身体映像を視覚遮断した状態で，仮想空間に設置した視認可能 な目標位置へ指先を一致させるタスクを設けた。(ポインティングタスクと称する) このタスクをスイッチングタ スクの前後に実施することで，指先位置の関係から身体図式の変化を推定することが可能である．本論文ではス イッチングタスク前に測定した指先位置をポインティング位置 $B$, スイッチングタスク後に測定した指先位置をポ インティング位置 $A$ と呼称する. 本評価手法は (Oyama et al., 2002) (Prablanc et al., 1979) から着想を得て考案した ものである.

また本評価方法では, 単にポインティング位置 $A, B$ の差分を世界座標系において導出するのではなく, 意図し た形状への身体図式の変化（今回は肘から手首に向かう方向への右前腕の伸長）を測定するために，はじめにポ インティング位置に対して，身体図式を伸長させる方向の成分のみを抽出する処理を施している．評価指標を導 出する手順について以下に説明する.

まず目標位置を原点, 肘から手首に向かう方向を $x$ 軸正方向, 掌から手の甲へ向かう方向を $z$ 軸正方向, $X Z$ 平面 の法線方向を $y$ 軸として腕座標系を定義する．そして座標変換により腕座標系におけるポインティング位置 $A_{\text {arm }}$, $B_{\text {arm }}$ をそれぞれ求める。 この時, $A_{\text {arm }}$ と $B_{\text {arm }}$ を結ぶベクトル $\overrightarrow{A_{a r m} B_{\text {arm }}}$ を $\boldsymbol{E} \boldsymbol{V}$ とすると, $\boldsymbol{E} \boldsymbol{V}$ の $x$ 成分が身体図 式の伸長量に該当する．また身体図式の変更手法では身体映像を伸長比として提示しているため, 比較が容易に できるよう次元を合わせる必要がある。 そこで伸長量 $\boldsymbol{E} \boldsymbol{V}$ の $x$ 成分に対して実際の右前腕の長さで正規化を行い, 右前腕の実寸に対する寸法比（実測寸法比 MD）という形に変換する。この值が身体図式の変化の評価指標とな る.ここで，ポインティングタスクおよび評価指標の導出手順のイメージを図 4 に示す.

\section{3. 触力覚提示を伴う身体図式変更手法}

前章で説明した身体図式の変更手法は, VR 情報の視覚提示に留まっていた。本論文の目的は, 触力覚提示機能 を追加し，その際の変更特性への影響について調べることである.そこで本節では, 触力覚の概念とその提示方 法について説明する.

\section{$3 \cdot 1$ 触力覚の概念}

触力覚は触覚と力覚を合わせた概念である．触覚は，接触物の存在や材質などを感じ取った内容を意味してお り, 力覚は身体に加わる力を感じ取った内容を意味している.そのため, 触力覚は皮膚感覚（特に圧覚, 振動覚, 痛覚）と固有受容感覚が統合されることで知覚される. 触力覚は実世界において環境と接触を持つ際に当然のよ 

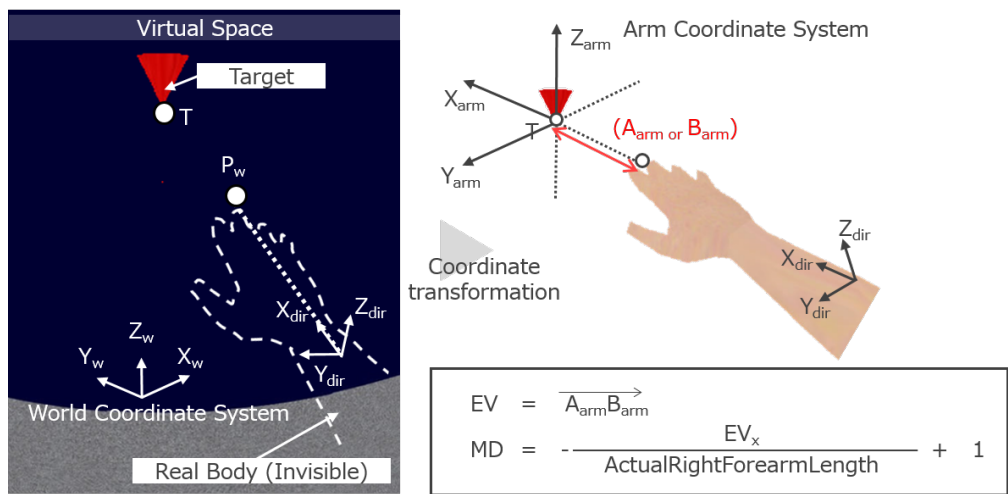

Fig. 4 Pointing task and calculation of the updated level of body schema.

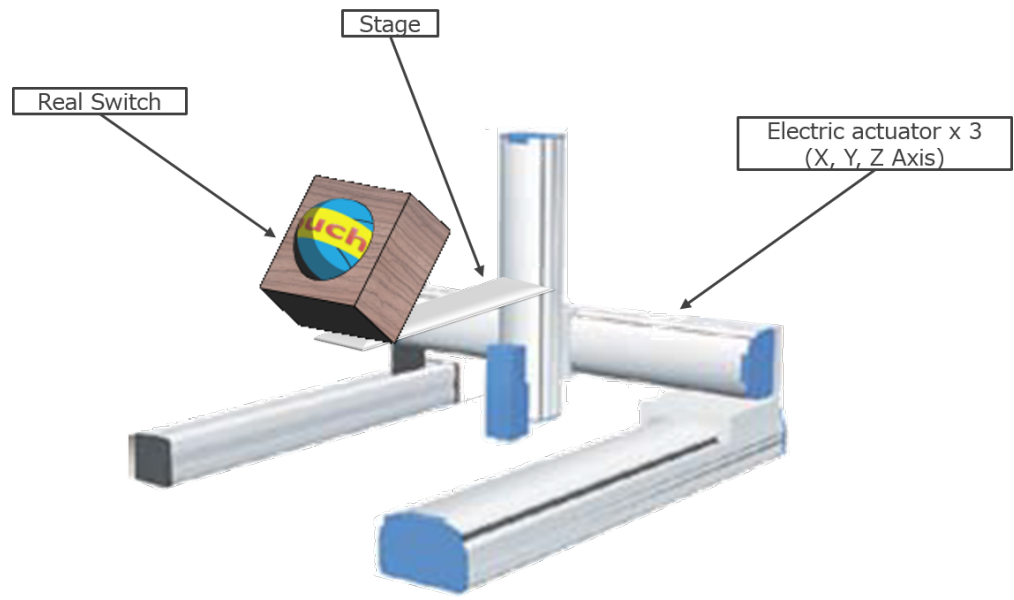

Fig. 5 Haptic device designed for switching tasks.

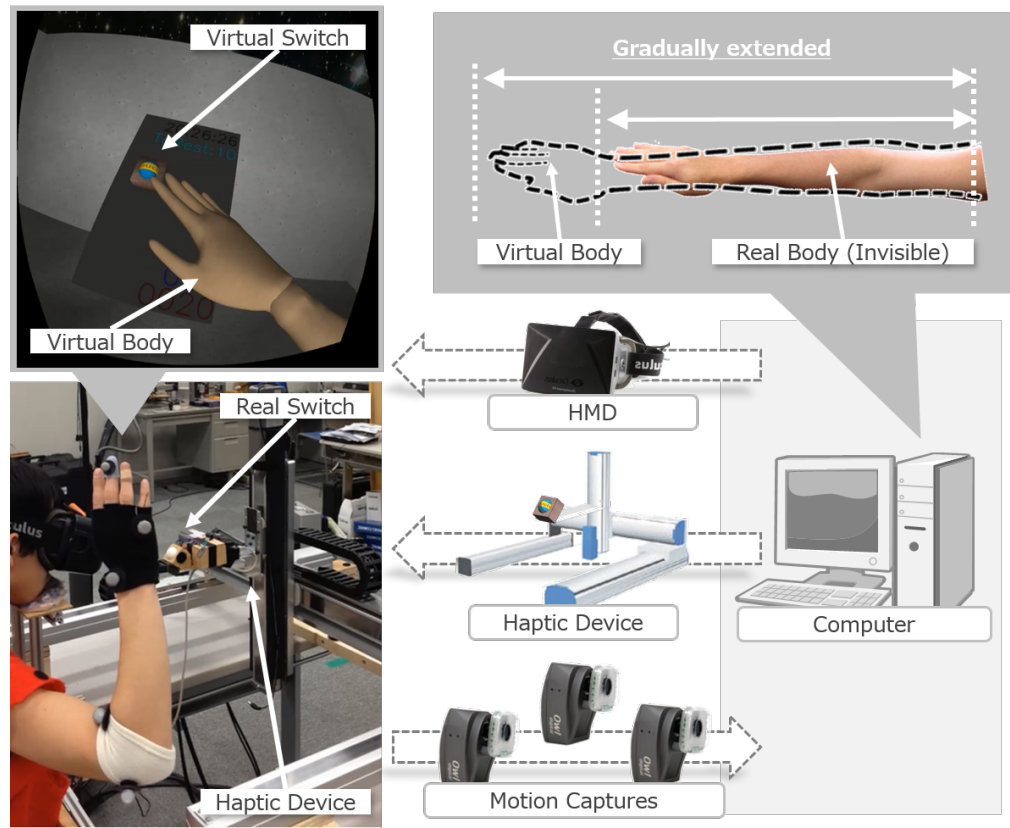

Fig. 6 Overview of system configuration with haptic interface function. 


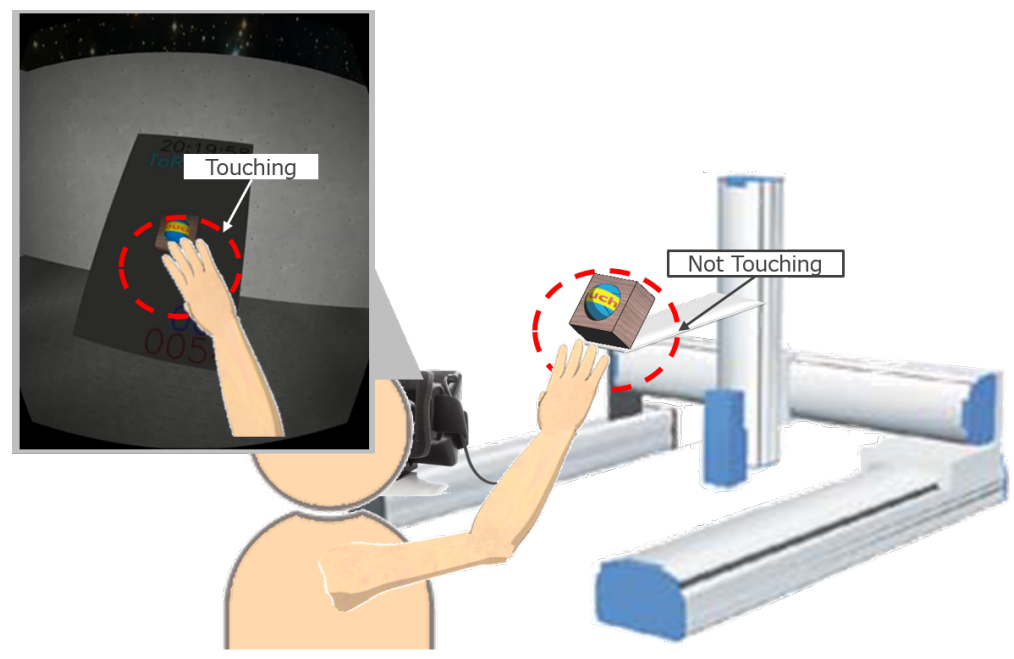

Fig. 7 The trouble which happens in the switching-task (using extended virtual body), in case the virtual switch and the real switch are located in the same position.

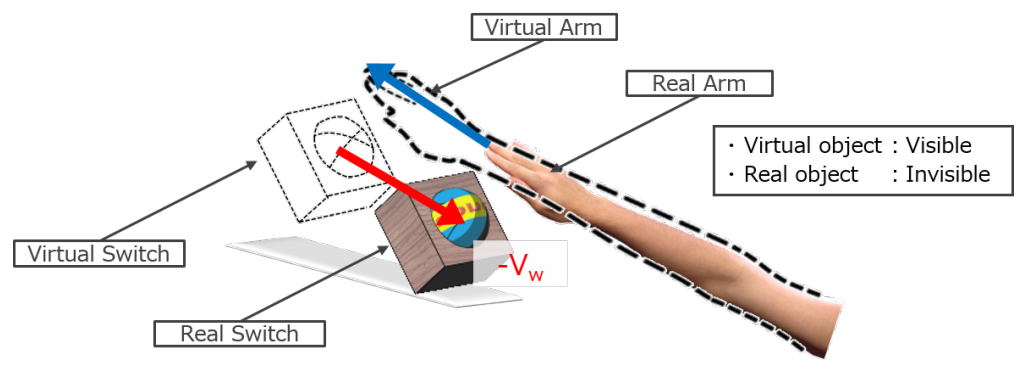

Fig. 8 Solution to reduce the mismatch between visual and haptic informations.

うに生起する感覚情報であるため，その追加が身体図式の変更に与える影響を知ることは重要である.

\section{$3 \cdot 2$ 触力覚情報の付加方法}

本研究では, 提案手法に触力覚情報を追加するための方法として, 図 5 に示すデバイスを用意した. 図 5 はス イッチングタスク中に出現する仮想スイッチと同形状の実スイッチを，3 次元で位置決め可能なステージに取り付 けたものであり，仮想スイッチの位置変化に連動させた実スイッチの移動を可能とする．これを仮想身体で仮想ス イッチに触れた際に，実身体でも実スイッチに接触するよう制御することで，高再現度での触力覚提示が可能と なる.ここで, 先行研究において構築したシステムに触力覚提示デバイス（図 5）を組み込んだ最終的なシステム 構成を図 6 に示す.

ただし，図 5 のデバイスにおいて単純に仮想スイッチと実スイッチの位置合わせを行った場合，仮想身体右前腕 の伸長に伴い, 視覚-触力覚の知覚位置に不整合が生じることに注意する必要がある. その様子を図 7 に示す．そ のため, 仮想身体右前腕の伸長量をべクトル $\boldsymbol{V} \boldsymbol{w}$ として定義し, このベクトルの分だけ実スイッチの位置を反対 方向に並進移動させることとした（図 8）.

また実スイッチ移動時の軌道は, 実身体との不用意な接触やスイッチ押下時の位置誤差などのノイズが発生し ないよう，スイッチングタスクのモーションを考慮して制御した。

\section{4. 実験}

前章にて説明した触力覚提示デバイスによる触力覚フィードバックが, 身体図式の変更にどのような影響を及 ぼすか, 以下 2 条件における比較実験を行った。

(1) 触力覚フィードバック無し 


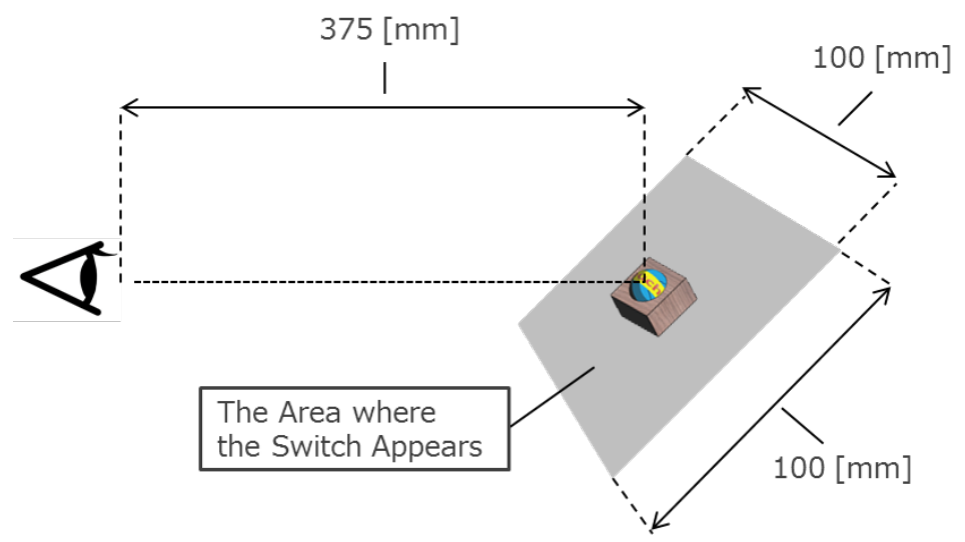

Fig. 9 The relation of the distance from user to switch and the area where the switch appears.

著者らが先行研究で扱った従来手法 (Nakamura et al., 2014) (依田他, 2015)（2.1 を参照）である. ハイブリッ ド学習を適用したスイッチングタスクにより身体図式を変更し，その変化をポインティングタスクによって 評価する.

(2) 触力覚フィードバック有り

本論文で取り上げる手法（3.2 を参照）である．従来のスイッチングタスクに触力覚フィードバック機能を追 加した変更手法であり, その変化を従来と同様のポインティングタスク（触力覚フィードバック無し）にて 評価する.

\section{$4 \cdot 1$ 実験手順}

実験の手順は以下の通りである.

まず2-1-(1)で述べた方法にて視・触覚同期刺激を提示し，仮想身体への自己所有感を向上させる．続いてポイ ンティングタスクを行い, 身体図式変更前のポインティング位置 $B$ を測定する. 次にスイッチングタスクを実施 し, 身体図式の変更を促す。この時, 仮想身体で提示した寸法比（提示寸法比 PD）は 1.0 倍, 1.4 倍の 2 通りとし た。またハイブリッド学習の実現のため, 仮想身体を表示させた状態でのスイッチング 3 回と, 非表示状態での スイッチング 2 回を交互に行わせた。提示寸法比 PD は 100 回で目標值となるよう線形変化させ, 目標值にて 200 回まで継続させた。

そしてスイッチング終了後, 再度ポインティングタスクを実施し, 身体図式変更後のポインティング位置 $A$ を 測定した。測定したポインティング位置 $A, B$ は, それぞれ 2-2で述べた処理を行い, 身体図式変更の実測寸法比 MDを算出した.

なおスイッチが出現する位置は，成人男性の腕で十分届く範囲となるよう，図 9 に示すように設定した。また 実験単位での運動パターンのばらつきを抑制するために，椅子に着座した状態で顎を固定台に乗せるよう指示を 行い, 実験時の姿勢の統一を図った。

以上の手順にて, 本研究に関する知識を持たない健常者 4 名（21-22 歳, 男性, 右利き) に対して, 触力覚フィー ドバック有りと無し，それぞれ繰り返し 4 回の実験を行った。なお順序効果の影響を排除するため，各実験は別 日にランダムで実施した。

\section{$4 \cdot 2$ 実験結果}

実験で得られた実測寸法比 MDに対して，それぞれ被験者ごとに平均を取り，これを分析用のデータとして用 いることとする．ここで，触力覚フィードバック有りと無しについて，提示寸法比 PD に対する実測寸法比 MD の 結果を図 10 に示す.どちらの場合においても, 提示寸法比 PD に応じて実測寸法比 MD が変化していることが確 認でき，提示寸法比 1.4 における身体図式の変化率は，共に約 $50 \%$ という結果になった. 


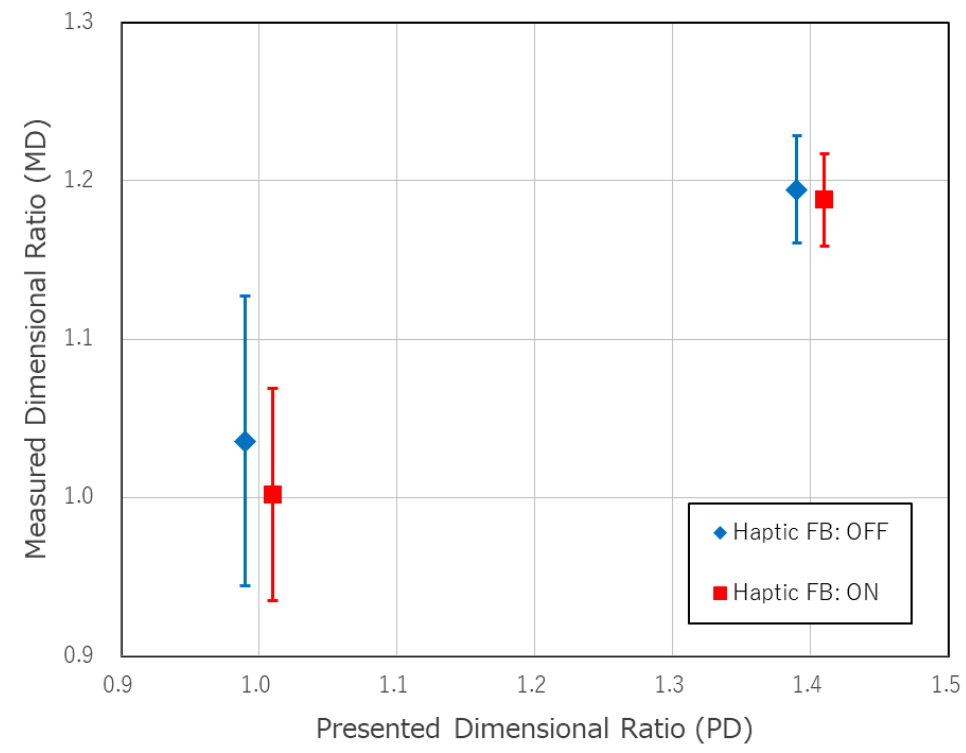

Fig. 10 Mean and standard deviation of the post-update dimensional ratio of all subjects for each presented dimensional ratio.

続いて, 触力覚フィードバックの有無と提示寸法比 PD（1.0 倍, 1.4 倍) をそれぞれ独立変数に, 実測寸法比 MD 従属変数として, Two-Way Repeated Measures ANOVA を行った。 その結果，提示寸法比 PD では有意差が認められ たが $\left(p=1.03 \times 10^{-4}<0.001\right)$, 触力覚フィードバックの有無による有意差は認められなかった $(p=0.517>0.05)$. なお各条件のデータは何れも正規分布に従っており（Shapiro-Wilk 検定: $p>0.05$ ), 各条件間の等分散性は Bartlett 検定により確認している $(p=0.224>0.05)$.

\section{3 考察}

まず身体図式の変更において，触力覚フィードバックの有無が非有意であったことについて考察する.

触力覚フィードバックとは, 物体との接触による触覚および物体からの反力による力覚といった触力覚情報を 人間に提示することである。ここで, 身体図式は身体像の教師信号を体性感覚と意識的に紐づけることで学習さ れるため, 知覚された触力覚は体性感覚の意識化に貢献するものと考えられる.しかしながら, 提案手法では八 イブリッド学習の適用により意識化が十分に実現されており, その結果として, 触力覚提示において有意差がみら れなかった可能性が一つ考えられる. なお, この仮説については, ハイブリッド学習を排除した条件にて, 別途 検証していく必要があると思われる。

続いて, 実験結果について実用性という観点で考えると, 統計上発生し得る寸法差が約 $\pm 15 \%(3 \sigma)$ なのに対し て, 視覚のみでの実測寸法比 MD が 1.2 倍程となっており, 変更度合いという点では既に満足する結果が得られて いる，従って，本論文がターゲットとする用途においては，本条件での身体図式の変更に対して触力覚の追加は 必須ではない可能性が示唆された。ただし, 今回被験者数が 4 名と比較的少数であったことを踏まえると, より 信頼性の高い知見として確立するためには, 被験者の増員が必要になると思われる. また提案手法でのパラメー タ（伸長比の大きさなど）によっては, 触力覚提示が有意となる可能性が残されており, 実用上要求されるスペッ クに応じて，別途検討が必要になることも想定されよう.

\section{5. ま と め}

本論文では，著者らがこれまでに研究を進めてきた，VR システムにおける身体図式キャリブレーションに関し て, 触力覚フィードバックが及ぼす影響の調査を行った。その結果, 触力覚フィードバックの有無による有意差は 認められなかった。これにより，人型仮想アバタやテレイグジスタンスの操作性向上に向けた身体図式の変更とい う用途において, 触力覚情報の追加提示は必須でない可能性が示唆された.つまりこれは, 著者らが目指すシス 
テムの構築にあたり, 触力覚情報の提示機能は省いても差し支えないことを示している.

今後は，仮想身体の収縮や回転における身体図式の変更といった基礎特性の導出を進めていき，さらに身体定 位に関わる感覚情報の一つでもある聴覚情報についてもその影響を調査していく所存である. また実用に向けて, 身体図式キャリブレーションによる操作性向上を確認する必要があるともに, 効果向上を狙った提案手法のパラ メータ調整についても並行して実施していく予定である.

\section{文献}

Botvinick, M. and Cohen, J., Rubber hands ' feel' touch that eyes see, Nature, Vol.391(1998), p.756.

Bromage, R. P. and Melzack, R., Phantom limbs and the body schema, Canadian Anaesthetists Society Journal, Vol.21, No.3(1974), pp.267-274.

Burdea, C. G., Invited review: The synergy between virtual reality and robotics, IEEE Transactions on Robotics and Automation, Vol.15, No.3(1999), pp.400-410.

Bushnell, E. and Boudreau, J., Motor development and the mind: The potential role of motor abilities as a determinant of aspects of perceptual development, Child Develop, Vol.64, No.4(1993), pp.1005-1021.

Cardinali, L., Brozzoli, C., Urquizar, C., Salemme, R., Roy, A. C. and Farne, A., When action is not enough tool-use reveals tactile-dependent access to body schema, Neuropsychologia, Vol.49, No.13(2011), pp.3750-3757.

Digital Human Research Group, HIRI, AIST, 人体寸法・形状データベース 2003, 〈https://www.dh.aist.go.jp/database/fbodyDB/index.html〉, (参照日 2017 年 4 月 15 日).

Fang, Y. and Wu, B., Research on teleoperation surgery simulation system based on virtual reality, Intelligent Control and Automation (WCICA)(2014).

Fuke, S., Ogino, M. and Asada, M., Acquisition of the head-centered peri-personal spatial representation found in VIP Neuron, IEEE Transactions on Autonomous Mental Development, Vol.1, No.2(2009), pp.131-140.

Furukawa, M., Ando, H. and Maeda, T., The giant experimance : Visual transfer design to virtually extend the user' s body, International Conference on Artificial Reality and Telexistence, Eurographics Symposium on Virtual Environments(2014).

Giuseppe, R., Virtual reality as communication tool: A sociocognitive analysis, Presence, Vol.8, Issue 4(1999).

Head, H. and Holmes, G., Sensory disturbances from cerebral lesions, Brain, Vol.34(1911), pp.102-245.

Hightower, D. J., Sumith, C. D. and Wiker, F. S., Development of remote presence technology for teleoperator systems, 14th Meeting of the United States-Japan Natural Resources Committee(1986).

Maravita, A. and Iriki, A., Tools for the body (schema), Trends in Cognitive Sciences, Vol.8, No.2(2004), pp.79-86.

Nakamura, S., Mochizuki, N., Konno,T., Yoda, J. and Hashimoto, H., Research on updating of body schema using AR limb and measurement of the updated value, IEEE Systems Journal, Vol.10, Issue 3(2016), pp.903-911.

大山英明, 前田太郎, 舘 暲, SF と科学技術におけるテレイグジスタンス型ロボット操縦システムの歴史, 日本バー チャルリアリティ学会論文誌, Vol. 7, No.1(2002), pp.59-68.

Oyama, E., Maeda, T., Tachi, S., MacDorman, K. F. and Agah, A., On the use of forward kinematics models in visually guided hand position control - analysis based on ISLES model, Neurocomputing, Vol.44(2002), pp.965-972.

Oyama, E., Tsunemoto, N., Inouse, Y. and Tachi, S., Experimental study on remote manipulation using virtual reality, PRESENCE, Vol.2, No.2(1993), pp.112-124.

大山英明, 常本直貴, 前田太郎, 舘 暲, 仮想環境と実環境の重ね合わせのための一手法, 日本ロボット学会誌, Vol.12, No.2(1994), pp.272-281.

Prablanc, C., Echallier, J. F., Komilis, E. and Jeannerod, M., Optimal response of eye and hand motor systems in pointing at a visual target, Biological Cybernetics, Vol. 35, Issue 2(1979), pp 113-124.

Roger, N., Helen, G. and Catherine, P., University of Nottingham, UK, Winner of the Best Visual Illusion of the Year Contest 2012, 〈https://www.youtube.com/watch?v=Qcm0_QPhLe4〉, (accessed on 15 April, 2017).

Roschin, V. Y., Frolov, A. A., Burnod, Y. and Maier, M. A., A neural network model for the acquisition of a spatial body scheme through sensorimotor interaction, Neural Computation, Vol.23, No.7(2011), pp.1821-1834. 
Sanchez-Vives, M. V., Spanlang, B., Frisoli, A.,Bergamasco, M. and Slater, M., Virtual hand illusion induced by visuomotor correlations, PLoS One, Vol.5, No.4(2010), e10381.

Sato, M., Teleoperator / telepresence system (TOPS) concept verification model (CVM) development, Recent Advances in Marine Science and Technology(1992), pp.97-104.

Slater, M., Perez-Marcos, D., Ehrsson, H. H. and Sanchez-Vives, M. V., Towards a digital body: The virtual arm illusion, Front Hum Neurosci, Vol.2, No.6(2008).

Stark, L., Kim, W. S., Tendick, F. and Hannaford, B., Telerobotics: Display, control, and communication problems, IEEE Journal of Robotics and Automation, Vol.3, No.1(1987), pp.67-75.

Tachi, S., Arai, H. and Maeda,T., Tele-existence simulator with artificial reality, IEEE International Workshop on Intelligent Robots and Systems(1988).

Tajadura-Jimenez, A., Valjamae, A., Toshima, I., Kimura,T., Tsakiris, M. and Kitagawa, N., Action sounds recalibrate perceived tactile distance, Current Biology, Vol.22(2012), pp.516-517.

Tsakiris, M., Carpenter, L., James, D. and Fotopoulou, A., Hands only illusion: Multisensory integration elicits sense of ownership for body parts but not for non-corporeal objects, Experimental Brain Research, Vol.204, No.3(2010), pp.343-352.

渡邊孝一, 川上直樹, 舘 暲, テレイグジスタンス・マスタスレーブシステムにおける操縦者とスレーブロボットとの 間の寸法不一致の影響, 日本バーチャルリアリティ学会論文誌, Vol.14, No.3(2009), pp.391-394.

柳田康幸, 舘 日章, HMD 型テレイグジスタンスシステムの頭部運動時における視野角不整合の影響, 日本バーチャル リアリティ学会論文誌, Vol.7, No.1(2002), pp.69-78.

依田淳也, 中村壮亮, 昆野友樹, 望月典樹, 橋本秀紀, AR 肢体を用いた身体位置感覚更新が運動軌道に与える影響の 評価, 日本機械学会論文集, Vol.81, No.829(2015), DOI:10.1299/transjsme, 15-00249.

Yuan, Y. and Steed, A., Is the rubber hand illusion induced by immersive virtual reality?, IEEE Virtual Reality Conference(2010), pp.95-102.

\section{References}

Botvinick, M. and Cohen, J., Rubber hands ' feel' touch that eyes see, Nature, Vol.391(1998), p.756.

Bromage, R. P. and Melzack, R., Phantom limbs and the body schema, Canadian Anaesthetists Society Journal, Vol.21, No.3(1974), pp.267-274.

Burdea, C. G., Invited review: The synergy between virtual reality and robotics, IEEE Transactions on Robotics and Automation, Vol.15, No.3(1999), pp.400-410.

Bushnell, E. and Boudreau, J., Motor development and the mind: The potential role of motor abilities as a determinant of aspects of perceptual development, Child Develop, Vol.64, No.4(1993), pp.1005-1021.

Cardinali, L., Brozzoli, C., Urquizar, C., Salemme, R., Roy, A. C. and Farne, A., When action is not enough tool-use reveals tactile-dependent access to body schema, Neuropsychologia, Vol.49, No.13(2011), pp.3750-3757.

Digital Human Research Group, HIRI, AIST, Human body size / shape database 2003, 〈https://www.dh.aist.go.jp/database/fbodyDB/index.html〉, References (accessed on 15 April, 2017).

Fang, Y. and $\mathrm{Wu}, \mathrm{B}$., Research on teleoperation surgery simulation system based on virtual reality, Intelligent Control and Automation (WCICA)(2014).

Fuke, S., Ogino, M. and Asada, M., Acquisition of the head-centered peri-personal spatial representation found in VIP Neuron, IEEE Transactions on Autonomous Mental Development, Vol.1, No.2(2009), pp.131-140.

Furukawa, M., Ando, H. and Maeda, T., The giant experimance : Visual transfer design to virtually extend the user' s body, International Conference on Artificial Reality and Telexistence, Eurographics Symposium on Virtual Environments(2014).

Giuseppe, R., Virtual reality as communication tool: A sociocognitive analysis, Presence, Vol.8, Issue 4(1999).

Head, H. and Holmes, G., Sensory disturbances from cerebral lesions, Brain, Vol.34(1911), pp.102-245.

Hightower, D. J., Sumith, C. D. and Wiker, F. S., Development of remote presence technology for teleoperator systems, 14th Meeting of the United States-Japan Natural Resources Committee(1986). 
Maravita, A. and Iriki, A., Tools for the body (schema), Trends in Cognitive Sciences, Vol.8, No.2(2004), pp.79-86.

Nakamura, S., Mochizuki, N., Konno,T., Yoda, J. and Hashimoto, H., Research on updating of body schema using AR limb and measurement of the updated value, IEEE Systems Journal, Vol.10, Issue 3(2016), pp.903-911.

Oyama, E., Maeda, T. and Tachi, S., Telexistence robots: Facts and fiction, Transactions of the Virtual Reality Society of Japan, Vol. 7, No.1(2002), pp.59-68(in Japanese).

Oyama, E., Maeda, T., Tachi, S., MacDorman, K. F. and Agah, A., On the use of forward kinematics models in visually guided hand position control - analysis based on ISLES model, Neurocomputing, Vol.44(2002), pp.965-972.

Oyama, E., Tsunemoto, N., Inouse, Y. and Tachi, S., Experimental study on remote manipulation using virtual reality, PRESENCE, Vol.2, No.2(1993), pp.112-124.

Oyama, E., Tsunemoto, N., Maeda, T. and Tachi, S., A method for superimposing virtual environment and real environment, Journal of the Robotics Society of Japan, Vol.12, No.2(1994), pp.272-281(in Japanese).

Prablanc, C., Echallier, J. F., Komilis, E. and Jeannerod, M., Optimal response of eye and hand motor systems in pointing at a visual target, Biological Cybernetics, Vol. 35, Issue 2(1979), pp 113-124.

Roger, N., Helen, G. and Catherine, P., University of Nottingham, UK, Winner of the Best Visual Illusion of the Year Contest 2012, 〈https://www.youtube.com/watch?v=Qcm0_QPhLe4〉, (accessed on 15 April, 2017).

Roschin, V. Y., Frolov, A. A., Burnod, Y. and Maier, M. A., A neural network model for the acquisition of a spatial body scheme through sensorimotor interaction, Neural Computation, Vol.23, No.7(2011), pp.1821-1834.

Sanchez-Vives, M. V., Spanlang, B., Frisoli, A.,Bergamasco, M. and Slater, M., Virtual hand illusion induced by visuomotor correlations, PLoS One, Vol.5, No.4(2010), e10381.

Sato, M., Teleoperator / telepresence system (TOPS) concept verification model (CVM) development, Recent Advances in Marine Science and Technology(1992), pp.97-104.

Slater, M., Perez-Marcos, D., Ehrsson, H. H. and Sanchez-Vives, M. V., Towards a digital body: The virtual arm illusion, Front Hum Neurosci, Vol.2, No.6(2008).

Stark, L., Kim, W. S., Tendick, F. and Hannaford, B., Telerobotics: Display, control, and communication problems, IEEE Journal of Robotics and Automation, Vol.3, No.1(1987), pp.67-75.

Tachi, S., Arai, H. and Maeda,T., Tele-existence simulator with artificial reality, IEEE International Workshop on Intelligent Robots and Systems(1988).

Tajadura-Jimenez, A., Valjamae, A., Toshima, I., Kimura,T., Tsakiris, M. and Kitagawa, N., Action sounds recalibrate perceived tactile distance, Current Biology, Vol.22(2012), pp.516-517.

Tsakiris, M., Carpenter, L., James, D. and Fotopoulou, A., Hands only illusion: Multisensory integration elicits sense of ownership for body parts but not for non-corporeal objects, Experimental Brain Research, Vol.204, No.3(2010), pp.343-352.

Watanabe, K., Kawakami, N. and Tachi, S., An effect of dimensional disagreement between the operator and the slave robot in telexistence master-slave system, Transactions of the Virtual Reality Society of Japan, Vol.14, No.3(2009), pp.391-394(in Japanese).

Yanagida, Y. and Tachi, S., Dynamic effects of inconsistent field of view in HMD-based telexistence systems, Transactions of the Virtual Reality Society of Japan, Vol.7, No.1(2002), pp.69-78(in Japanese).

Yoda, J., Nakamura, S., Konno, T., Mochizuki, N. and Hashimoto, H., Effect of the update of position sense using AR-limb on the motion trajectory, Transactions of the JSME (in Japanese),Vol.81, No.829(2015), DOI:10.1299/transjsme, 1500249.

Yuan, Y. and Steed, A., Is the rubber hand illusion induced by immersive virtual reality?, IEEE Virtual Reality Conference(2010), pp.95-102. 